\title{
Chapter 3 \\ Hydropower Politics and Conflict on the Salween River
}

\author{
Carl Middleton, Alec Scott and Vanessa Lamb
}

\subsection{Introduction}

This chapter examines the hydropower politics of the Salween River, with a focus on the projects proposed in Myanmar and their connections with neighboring China and Thailand via electricity trade, investment, and regional geopolitics. We do so through a lens of hydropolitics to contextualize and better reveal the contested nature of these projects and their connections. We attend in particular to the Salween River in Myanmar, where there is a complex history of conflict and multiple associated claims for territory, political authority, and legitimacy (Stokke et al. 2018). Underscoring these links, even the 2017 strategic environmental impact assessment (SEIA) baseline study of Myanmar's hydropower electricity sector commissioned by the International Finance Corporation (IFC) states that "natural resource exploitation is linked to armed violence, including hydropower development" (ICEM 2017: 17). In this context, the terrain and assumptions of conventional water governance analysis are unsettled, which in turn supports the value of a critical hydropolitics analysis as undertaken in this chapter.

Plans for dams in the Salween Basin in Myanmar and Thailand have existed since the late 1970s, but gained momentum post-1988 as Myanmar's military government began deepening trade and investment relations with China and Thailand (Paoletto/ Uitto 1996; Magee/Kelley 2009). Around 18 large hydropower projects of varying scales have been proposed for the $\mathrm{Nu}$ Jiang-Salween basin mainstream (Fig. 3.1: Planned dams on the mainstream Nu Jiang - Salween River). An important context

Dr. Carl Middleton, Director, Center of Excellence for Resource Politics in Social Development, Center for Social Development Studies, Faculty of Political Science, Chulalongkorn University; Email: Carl.Chulalongkorn@gmail.com.

Alec Scott, Regional Water Governance Technical Officer, Karen Environmental and Social Action Network (KESAN): Email: scottsangpo@gmail.com.

Dr. Vanessa Lamb, Lecturer, School of Geography, University of Melbourne, Melbourne, Australia; Email: vanessa.lamb@unimelb.edu.au.

(C) The Author(s) 2019

C. Middleton and V. Lamb (eds.), Knowing the Salween River: Resource Politics

of a Contested Transboundary River, The Anthropocene: Politik-Economics-

Society—Science 27, https://doi.org/10.1007/978-3-319-77440-4_3 


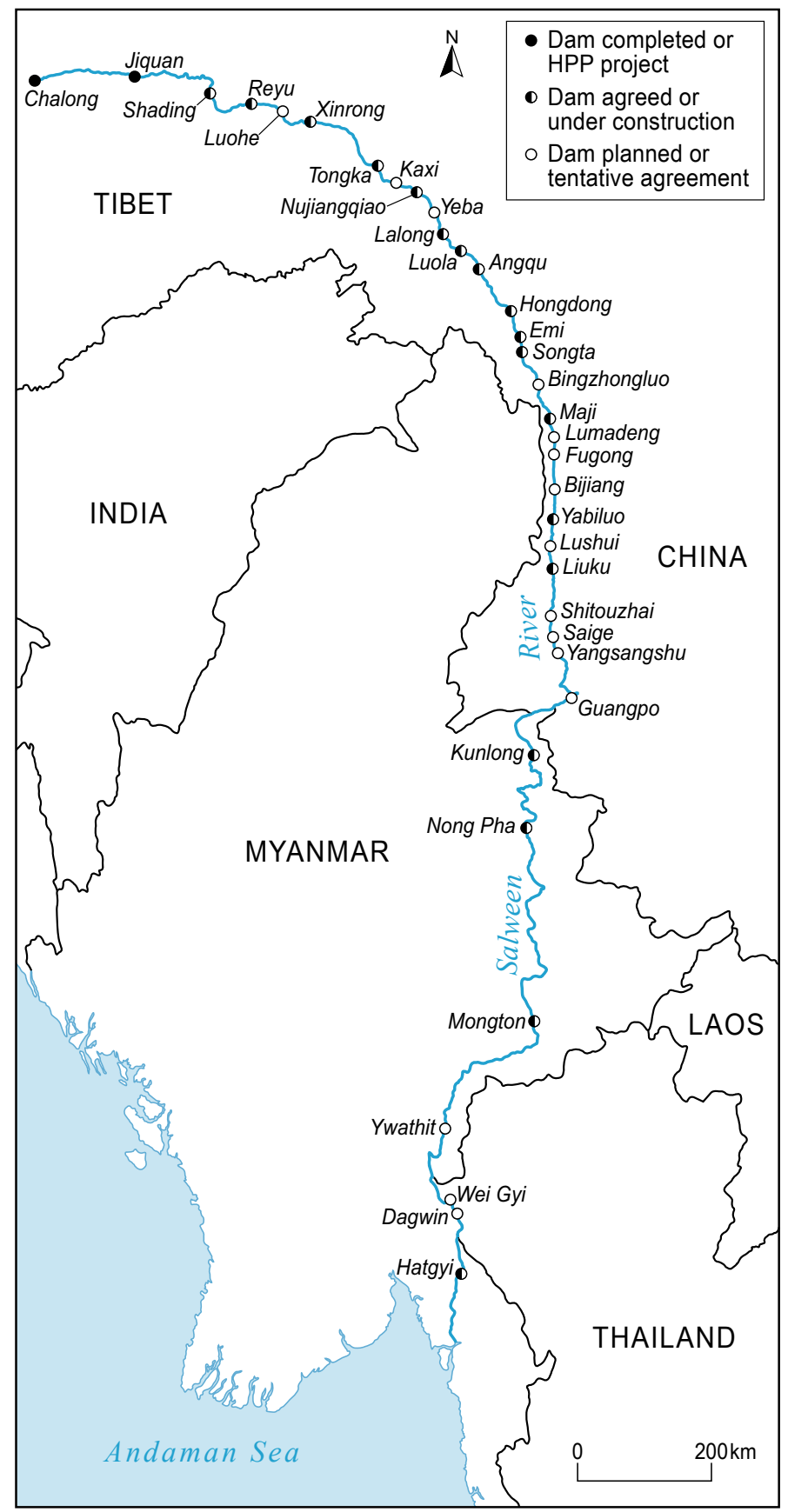

Fig. 3.1 Planned dams on the mainstream Nu Jiang - Salween River. Source Cartography by Chandra Jayasuriya, University of Melbourne, with permission 
to these projects is the seven-decade-long history of modern conflict in Myanmar. ${ }^{1}$ Indeed, the link between hydropower infrastructure and conflict in the Salween basin is significant (BEWG 2017; Burke et al. 2017). The plans for large hydropower are not a 'new' endeavor, but one that has been pursued (and contested) incrementally over decades, with engagements from multiple actors acting across multiple scales. These actors include the Union government, domestic conglomerates, transnational corporations and consultants, political parties, Ethnic Armed Organizations (EAOs), Myanmar's armed forces (the Tatmadaw) and civil society organizations (CSOs).

To expand on and explore the Salween's multi-faceted hydropolitics, the immediately following section outlines some of the key aspects of the relevant hydropolitics literature and approach. It also identifies what a hydropolitics analysis of the Salween River, with a focus on the Myanmar context, can bring to our understanding of the basin's complex history and range of engagements. The following section then provides a brief history of the plans for large dams on the Salween River mainstream and major tributaries, and the current known project status, before presenting an analysis of how Salween hydropower projects have been incorporated into transboundary and national plans for electricity trade. We then present an analysis of the relationship between Myanmar's peace negotiations, conflict and the hydropower dams, and in the following section the work that has been undertaken by civil society across scales including in the context of this conflict. We also consider how water governance has been structured across scales. Finally, we bring these themes and their associated actors and their engagements over time together in discussion to consider the ways these histories and developments, and their complex relationships with conflict in the area, shape Salween hydropolitics.

\subsection{Hydropolitics: Linking Subnational and Cross-Border Governance to Contests and Conflicts over Water}

In introducing "a critical hydropolitics", Sneddon/Fox (2006: 183) argue for an approach that "stands in contrast to mainstream studies of water resource development, transboundary waters, and international rivers." Their work is positioned in contrast to, for instance, the "water wars" thesis which argues that there is a looming water crisis at the state-to-state (geopolitical) level linked to water scarcity. Instead, Sneddon/Fox (2006: 182) explain that "These and similar works understand conflicts over water as limited almost exclusively to inter-state conflicts, and thus have very little to say about the multi-scalar, multi-actor character of water

\footnotetext{
${ }^{1}$ We use the term conflict here to refer to the various conflicts between the Myanmar armed forces (the Tatmadaw), operating under civilian (1948-1962), military-dominated one-party (19621988), military junta (1988-2010) and quasi-civilian (since 2010) governments, and various armed opposition movements that in some areas continue to this day (BEWG 2017; ICEM 2017; Bauer et al. 2018).
} 
politics." Instead, hydropolitics understands that the "politics of water" are intimately connected to constructions of territory-making and scale. As Rogers/ Crow-Miller (2017: 2) put forward in their review of hydropolitics literature:

\begin{abstract}
the key contributions of this collection of work [hydropolitics] have been to break down the nature-society dichotomy evident in hydraulic societies, to highlight the politics of access and exclusion, and to introduce into hydropolitical scholarship a more nuanced understanding of power relations by examining various forms of state- and market-driven water management.
\end{abstract}

Thus, hydropolitics is a useful lens for understanding the debates and contests around hydropower construction and water governance in the Salween basin. As we detail further in the following sections, in Myanmar's Salween River, subnational actors including EAOs, militias, and the Tatmadaw play a pivotal role in resource governance, acting alongside more conventionally-recognized hydropower actors such as government agencies responsible for electricity and water, and construction companies. The role of these armed actors also highlights ongoing (and evolving) concerns around conflict and peace as linked to control, ownership and management of natural resources in the basin. We also call attention to the role of CSOs (similar to Sneddon/Fox 2006), which have increasingly played influential roles in decision-making and shifting the scales of debate and inquiry.

The multi-scalar approach of a hydropolitics lens, which is less concerned with a local-state or local-global dichotomy, rather is interested in the ways that the politics of water are contested across and through multiple scales. Other studies in Southeast Asia have already revealed how civil society activists can contest uneven socio-economic and political processes and garner attention through contests over scale. For instance, Sneddon (2002), Lebel et al. (2005) and Molle (2007) show how civil society actors in the region have been integral not only to contesting scale, but to the production of scale, including through up-scaling efforts from a local scale to the scale of the basin and beyond in order to garner attention for their concerns. In the Salween Basin, 'scale-jumping' and the international-domestic links are useful to consider, but this does not mean that actors simply seek a 'natural' scale to jump to or to be 'chosen' as an existing frame or platform for analysis or political action. Instead, as Lamb (2014: 387) notes "scale must be actively defined, delimited, and populated with goals and concerns" (see also Götz, Chap. 6, this volume). In these ways, scales of analysis and decision-making are both considered as part of the process of understanding governance and politics of the Salween, but also, that these scales (of the nation, sub-nation, and local) are also produced and become subjects of action through these same processes.

In thinking about hydropower's role in particular, looking to the Mekong River, in a now-classic piece on that basin's hydropolitics, Bakker (1999) explains how an ingrained emphasis on hydropower development as 'the norm' in the region, rather than an understanding of hydropower as a contested project, is generative of both a politics of scale and justice. She further explains that the discourse around hydropower, 
operates as a 'politics of forgetting'; in presupposing rational allocation, it ignores the politicisation of water, thereby obscuring questions of equity of access, of control over prioritisation of projects, and of spatial and temporal scales of development. (Bakker 1999: 221)

Such an approach reveals how and why water becomes politicized, as well as who or what is included in these processes. As such, an approach towards the analysis of water that does not interrogate the proposition of hydropower development critically, or ask who is involved (or who is not), makes problematic assumptions about the terrain of debate, including about what constitutes 'cooperation' around water. As Sneddon/Fox (2006) further explain, an apolitical approach,

\footnotetext{
obscures the ways in which states, non-state actors and river basins themselves interact to construct 'transnational' basins through institutional and material processes. Cooperation in and of itself is not the desired end for third-world riparian governments who create transboundary governance institutions; rather, cooperation is perceived as the basis for proceeding with the development of water resources encompassed by basins. (emphasis in original, Sneddon/Fox 2006: 182)
}

In other words, an apolitical approach, not considerate of the politics of water, ignores much of the work and efforts by the multiple actors, across various scales, who contest hydropower development and thus may also rationalize overlooking these same actors when defining the terms for 'collaboration' moving forward. What a hydropolitical approach offers, then, is "reflective of critical theoretical and political concerns that go beyond mere calls for "cooperation"" (Sneddon/Fox 2006: 199). It is a call to critically understand and assess the politics of water, with attention to what it accomplishes for particular actors and across certain scales, as well as what it 'forgets.'

In the following sections, we detail how various schemes, plans and visions towards the Salween River have been formulated, with attention to the multiple actors and scales of analysis. To begin, we consider how these 'hydropolitics' are situated within the broader political economy of the region, particularly as linked to economic integration and (hydro)electricity cross-border trade (see also, Middleton/ Allouche 2016).

\subsection{Emergence and Current Status of Large Dam Plans on the Salween River}

The Salween Basin is located in a region undergoing significant change, including processes of regional economic integration and a growing demand for natural resources, food, electricity and commodities. In the 1990s, economic integration was promoted through the Asian Development Bank's (ADB's) Greater Mekong Subregion (GMS) program (ADB, 2012a) and since the mid-2000s, as a vision of the Association of South East Asian Nations' (ASEAN) economic integration leading up to the ASEAN Economic Community in 2015. Since the mid-2010s, the China-led Belt and Road Initiative and the associated Lancang-Mekong 
Cooperation Framework have further framed the region's economic integration, although its implications for the Salween are little known compared to more public plans for the Mekong River (Middleton 2018). These occur alongside other regional initiatives involving Japan, Korea, and the US among others.

As one of the main intended electricity markets, the role of Thailand's government and the fate of the country's economy has been central to plans for large dams on the Salween River mainstream in Myanmar. Preliminary studies for large dams on the Salween were initiated in the late 1970s, and addressed hydropower, irrigation and water transfer potential (Vatcharasinthu/Babel 1999). The Salween dam projects were first seriously considered in the late 1980s under Thai Prime Minister Chatichai Choonhaven (1988-1991), as the policy concept of turning "battlefields to marketplaces" gained traction (Magee/Kelley 2009). Building on this political momentum, in 1989, a Joint Working Group for the Development of Hydroelectric Projects on Border Rivers was established between the governments of Myanmar and Thailand tasked to prepare a feasibility study for projects along the Thai-Burma border (TERRA 2006). ${ }^{2}$

Correspondingly, the momentum for these projects have coincided at least partly with the rise and fall of Thailand's economy. The Asian Financial Crisis of 1997 in particular collapsed electricity demand in Thailand. As a result, Thailand's plans for power import projects from both Myanmar and Laos were put on hold (IRN 1999). At the same time, other bilateral issues were also creating tensions between the Myanmar and Thai governments, including boundary disputes, the production of and distribution of methamphetamines and heroin that were entering Thailand from Myanmar, and the conflict in Myanmar that resulted in refugees entering Thailand (Magee/Kelley 2009: 122). Plans for dams on the Salween mainstream reemerged in 2002 under the Thai Rak Thai government of Prime Minister Thaksin Shinawatra (2001-2006), when EGAT's Governor visited Myanmar to discuss the construction of the Weigyi and Dagwin dams on the border. Prime Minister Thaksin Shinawatra sought to work closely with Myanmar's military government to enable Thai investment, and Thailand affirmed its commitment to the projects on numerous occasions. For example, EGAT incorporated the Weigyi and Dagwin dams into its 2004-2016 Power Development Plan (PDP) as potential projects and in its 20072021 PDP included the Hatgyi and Tasang (now Mong Ton) dams as planned projects. Thus, between 1988 and 2010, under Myanmar's State Law and Order Restoration Council (SLORC) and subsequently the State Peace and Development Council (SPDC), plans to construct large hydropower dams on the Salween River accelerated.

Table 3.1: Proposed dams on the Salween River mainstream in Myanmar summarizes the current status of these mainstream hydropower projects on the

\footnotetext{
${ }^{2}$ Japan's Electric Power Development Company was commissioned by the Joint Working Group to prepare initial studies in the early 1990s and identified around ten dam sites with a total capacity of 6,400 MW at a cost of about USD 5.12 billion (Magee/Kelley 2009). The Joint Working Group was composed of representatives from the Myanmar Electric Power Enterprise, Thailand's National Energy and Policy Office and EGAT.
} 
Table 3.1 Planned dams on the Salween River mainstream in Myanmar

\begin{tabular}{|c|c|c|c|c|c|}
\hline Project & Location & $\begin{array}{l}\text { Reported } \\
\text { capacity } \\
(\mathrm{MW})\end{array}$ & Developers & $\begin{array}{l}\text { Power } \\
\text { market }\end{array}$ & Status \\
\hline Hatgyi & Karen State & 1,365 & $\begin{array}{l}\text { Sinohydro } \\
\text { (PowerChina), } \\
\text { EGATi (Thai), } \\
\text { MOEE (Myanmar), } \\
\text { International Group } \\
\text { of Entrepreneurs } \\
\text { (IGE) (Myanmar) }\end{array}$ & Thailand & $\begin{array}{l}\text { Joint Venture } \\
\text { Agreement, } \\
\text { Memorandum } \\
\text { of Agreement } \\
\text { (24 April } \\
\text { 2010) }\end{array}$ \\
\hline Dagwin & $\begin{array}{l}\text { Karen State/ } \\
\text { Mae Hong } \\
\text { Son Province }\end{array}$ & 729 & EGATi & Thailand & Cancelled \\
\hline Weigyi & $\begin{array}{l}\text { Karen State/ } \\
\text { Mae Hong } \\
\text { Son Province }\end{array}$ & 4,540 & EGATi & Thailand & Cancelled \\
\hline Ywathit & $\begin{array}{l}\text { Karenni State } \\
\text { (approx. } \\
45 \mathrm{~km} \\
\text { upstream of } \\
\text { Thai border) }\end{array}$ & 4,000 & $\begin{array}{l}\text { China Datang } \\
\text { Overseas } \\
\text { Investment Co., } \\
\text { Ltd., PowerChina, } \\
\text { MOEE, Shwe } \\
\text { Taung Group }\end{array}$ & $\begin{array}{l}\text { Reportedly } \\
\text { China }\end{array}$ & $\begin{array}{l}\text { Memorandum } \\
\text { of Agreement } \\
\text { (18 January } \\
\text { 2011) }\end{array}$ \\
\hline $\begin{array}{l}\text { Mong Ton } \\
\text { (previously } \\
\text { Tasang) }\end{array}$ & Shan State & 7,110 & $\begin{array}{l}\text { CTGC, Sinohydro, } \\
\text { China Southern } \\
\text { Power Grid, } \\
\text { EGATi, MOEE, } \\
\text { IGE }\end{array}$ & Thailand & $\begin{array}{l}\text { Memorandum } \\
\text { of } \\
\text { Understanding } \\
\text { (10 November } \\
2010)\end{array}$ \\
\hline Nongpha & Shan State & 1,200 & $\begin{array}{l}\text { HydroChina } \\
\text { (PowerChina) } \\
\text { MOEE, IGE }\end{array}$ & China & $\begin{array}{l}\text { Memorandum } \\
\text { of Agreement } \\
(22 \text { May 2014) }\end{array}$ \\
\hline Kunlong & Shan State & 1,400 & $\begin{array}{l}\text { Hanergy Holding } \\
\text { Group, } \\
\text { PowerChina, } \\
\text { MOEE, Gold Water } \\
\text { Resources (Asia } \\
\text { World) }\end{array}$ & China & $\begin{array}{l}\text { Memorandum } \\
\text { of Agreement } \\
(21 \text { May 2014) }\end{array}$ \\
\hline
\end{tabular}

Sources Salween Watch Coalition (2016); ICEM (2017); and IFC (2018)

Acronyms CTGC China Three Gorges Company; EGAT Electricity Generating Authority of Thailand; EGATi EGAT International Company; IGE International Group of Entrepreneurs; MOEE Ministry of Electricity and Energy (previously Ministry of Electric Power)

Salween River. While Thai and Myanmar government policy has a track record of broadly supporting plans for Salween dams, recent government statements waver between support and reservation. For example, in Myanmar in August 2016 at a press conference marking the National League for Democracy's 100 days in power, the Permanent Secretary of its Ministry of Electric Power said the Salween dams 
should move forward to address energy shortages in Myanmar (Myanmar Eleven 2016). Subsequently, in September 2016, Thailand's Permanent Secretary for energy announced that the Ministry of Energy planned further discussion with its Myanmar counterparts on Salween River hydropower dams (Deetes 2016). Yet, in 2017 Thailand's Ministry of Energy announced that it would not consider the Hatgyi Dam until there was an end to conflict in the area (Pollard 2018).

At present, four large hydropower projects have already been completed on two tributaries of the Salween River in Myanmar. ${ }^{3}$ Three are on the Baluchaung River (Baluchaung 1, 2 and 3) in Karenni State, which is a tributary of the Pawn River that is a major tributary of the Salween River, and one is on the Teng River in Shan State, namely the Kengtawng dam completed in 2009. Alongside the four completed projects, an additional nine large-dam projects are also at various stages of planning and construction on five major tributaries, with two at advanced stages of construction in Shan State on the Nam Teng and Baluchaung rivers.

Meanwhile, Memorandum of Agreement (MoA) have been signed for four large dams on the mainstream, not including the Mong Ton hydropower project (previously Tasang) which had reached an advanced stage of planning before the Myanmar government stated that it must be redesigned as a two-dam cascade in November 2016. Even as full-scale construction of mainstream Salween dams is yet to be initiated, preparatory work has been undertaken, including field site investigations, public consultations and, in some cases, preliminary construction work that has already resulted in some community resettlement and the exploitation of natural resources in project areas.

The tributary projects built in the Salween basin to date, while not much written about outside of Myanmar, are an important part of the contested history of conflict and displacement linked to development in the Salween basin. The Baluchaung 2 hydropower station (known locally as the Lawpita hydropower plant) was the first project, and was completed in 1974. It is fed by water diverted from the Mobye dam, and was the country's first large hydropower project constructed as part of a bilateral war reparation between Myanmar and Japan. ${ }^{4}$ For its construction, between 1969 and 1972 an estimated 8,000 people from 114 villages were forced to

\footnotetext{
${ }^{3}$ Here we focus on the Lower Salween, but plans in the Upper Salween or Nu Jiang, in Tibet and Yunnan Province, China for a 13-dam cascade on the mainstream also emerged in the late 1990s (Magee 2006). At present however, these projects have been suspended as government policies promoting national parks and protected areas have gained momentum (Yu et al. 2018; Yu et al., Chap. 4, this volume), and there are high electricity reserve margins across China's regional power grids as the economy has restructured reducing demand for new supply (Lin et al. 2016). However, the Nu Jiang's tributaries have been extensively dammed (Ptak 2014). These plans and their assessments and processes have similarly involved a whole range of actors, not limited to local and state governments, conservationists, engineers, and scientists.

${ }^{4}$ Local leaders in Pekhon Township formed an Anti-Dam Construction Committee in 1963 to rally against the construction of the Mobye dam which began in 1962. Met with threats of arrest and finding no recourse to justice, the committee founded the Kayan New Land Party (KNLP) as an armed resistance in 1964 (KDRG 2006: 35; KWU 2008: 1). Construction work at the dam site resumed in 1966.
} 
relocate from the Mobye dam's reservoir area (KDRG 2006; KWU 2008). The Baluchaung 1 hydropower plant, fed by water from the Dawtacha dam, was completed in 1992 during a period of heightened militarization and human rights violations as the Tatmadaw expanded its operations and bases in the area. Most recently, in 2015, construction work on the Baluchaung 3 hydropower plant was completed (MOEP 2011). Electricity from these projects is primarily transmitted to Yangon and Mandalay, while their local social and environmental legacy remains unaddressed.

Regarding specific projects proposed in Myanmar, there has been strong civil society concerns expressed about the social and environmental impacts. For instance, in the case of the proposed Mong Ton dam, affected residents protested the consultation meetings held in Shan State in 2015 by the Snowy Mountain Engineering Corporation (SMEC). Then, in 2016, for a variety of reasons, not all related to the stated public concerns, the Myanmar government requested that the dam be redesigned as two dams (EGATi 2016), leading to a team of Chinese experts restarting work at the site under military guard in 2018 (Yee 2018). There are similar concerns put forward about the impacts of the proposed Hatgyi dam, and, most recently the Kunlong and Naung Pha dams.

\subsection{Transboundary Electricity Trade and the Salween Dams}

The Salween River mainstream dams were conceived principally as cross-border power trade projects and were formulated within the context of the ADB GMS program for economic integration. Commissioned by the ADB in 1994, the Norwegian consultants Norconsult prepared an initial plan for regional power trade heavily based on large hydropower dam construction, including on the Salween River (Norconsult 1994). As plans for regional power trade evolved over the 1990s, the Tasang (now Mong Ton) dam in particular was identified as one to be incorporated into the regional power grid, exporting its power to Thailand. In 2002, the leaders of the GMS countries signed the Inter-Government Agreement on Regional Power Trade in the Greater Mekong Sub-Region Countries, which was a high-level endorsement to further plans for cross-border power trade in the region, and since then several further intergovernmental agreements have been signed (ADB 2012b). More recently, the GMS power trade plans have also been incorporated into a vision for an ASEAN-wide power grid (Affeltranger 2008). As plans have been furthered for the basin, the multi-scalar politics of these processes have been evident, as seen in their relationship to the regional power trade and grid, as well as through and across further scales - from the subnational to the bilateral and international - as well as across a range of actors, from states to conglomerates.

At the bilateral level, following several exchanges between government representatives in July 1996, an MoU was signed for 1,500 MW of power exports from Myanmar to Thailand, which expired in 2010. In May 2005, the governments of 
Thailand and Myanmar signed an MoU for the joint development of hydropower dams along the Salween River, which mandated EGAT and Myanmar's Department of Electric Power to jointly study in detail the locations and generating capacity of four large projects: Tasang (Mong Ton), Hatgyi, Weigyi (referred to as "Upper Salween") and Dagwin (referred to as "Lower Salween").

Some of the proposed Salween projects are intended to export their electricity to China, namely the Nongpha and Kunlong Dams, and potentially the Ywathit Dam. China already imports electricity from the Shweli 1 Dam on a tributary of the Irrawaddy River (completed in 2008) and the Dapein hydropower plant, while the controversial Myitsone Dam in Myanmar, suspended in 2011, was also designed principally as a power export project to neighboring Yunnan Province, China. Yet, with China now facing power surplus (Lin 2016), commitment to further power imports on first impression makes little sense. However, as highlighted by Ptak/ Hommel (2016), these planned power trade projects are not only intended for the purposes of Yunnan's and more broadly China's national electricity security. They also function to deepen regional interconnection and economic interdependence between China and Myanmar that overall serve China's geopolitical interest of closer ties with neighboring Southeast Asia, as well as securing opportunities for investment. More recently, however, plans have also been proposed for China to export electricity to Myanmar from Yunnan Province (Straits Times 2017).

Thailand's most recent Power Development Plan for 2015 to 2036 details hydropower imports from unspecified projects in Myanmar cumulatively increasing from 2027 onwards to a total of 6,300 MW, which overall would reflect a shift from 7 to $20 \%$ of Thailand's total electricity consumption met by imports (EPPO 2015). Thailand's electricity planners have long argued that Thailand needs to secure more electricity because current supplies are insufficient to meet its future demand and renewable energy and energy efficiency are insufficiently reliable, although these claims are also contested by civil society (Greacen/Greacen 2004; Delina 2018). The sector is heavily influenced by EGAT and large independent power producers, and has resulted in Thailand's highly centralized electricity system (Middleton/ Dore 2015). Large-scale power import projects, including the proposed hydropower dams on the Salween River, are meant to ensure Thailand's electricity security through diversifying sources (while not overly depending on power imports), reducing carbon emissions and diversifying fuel types away from gas.

In Myanmar, at present, there is no definitive plan for electricity sector development in the public domain. ${ }^{5}$ The current NLD-led government has sent mixed

\footnotetext{
${ }^{5}$ Since the transition to a semi-civilian government in 2010, there have been various plans prepared for meeting the country's electricity needs and these have been a priority for both the USDP-led and NLD-led governments. The Ministry of Electric Power, now the Ministry of Electricity and Energy (MOEE) has received significant technical and financial support from bilateral aid and multilateral financial institutions. Recently developed masterplans include: a National Electrification Plan by the World Bank published in 2015, a Myanmar Energy Master Plan (for primary energy sources) by the Asian Development Bank published in 2015, and ongoing support from the Japan International Cooperation Agency for a Power Sector Master Plan.
} 
messages on plans for hydropower on the Salween River. On the one hand, the NLD's election manifesto made a commitment not to build new large dams. On the other hand, as noted above, shortly after the NLD came to power, in August 2016 the Permanent Secretary of the Ministry of Electricity and Energy declared the government's commitment to construct large hydropower dams on the Salween River (Myanmar Eleven 2016). More recently, it seems that discussion has turned to the use of natural gas for domestic electricity generation, which some commentators have suggested should weaken the claim that the Salween dams are needed (Pollard 2018). At the same time, it has also been reported that the Minister for Electricity and Energy is still actively supportive of hydropower construction (Kean 2018).

Domestic conglomerates in Myanmar are also influential actors in hydropower. Three of Myanmar's largest conglomerates have won significant construction contracts in 11 out of 14 Salween hydropower projects and their associated infrastructure, including the Shwe Taung Group, International Group of Entrepreneurs (IGE), and Asia World Company (Table 3.1: Proposed dams on the Salween River mainstream in Myanmar). These companies were established under the previous military governments, and maintained close relationships with them thus becoming regarded as crony companies. While playing important roles in ceasefire negotiations between the Myanmar government and EAOs in the Salween basin, they have also used their political capital in business negotiations for hydropower contracts, winning lucrative deals in construction and concessions for natural resource extraction in the project areas.

Thus, the range of state and non-state private actors active to seek the construction of the Salween Dams is diverse and working across scales in Thailand, China and Myanmar. Drawing on their range of influences and resources, they have produced studies and formulated discourses rationalizing the need for the hydropower dams for cross-border and domestic electricity supply. While some tributary projects have already been built, to date the mainstream Salween in Myanmar remains free flowing. We now turn to focus on violent conflict in the Salween basin, and its implications for the hydropolitics of the basin.

\subsection{Myanmar's Peace Negotiations, Conflict and Hydropower Dams}

In November 2010, highly-flawed elections paved the way for the military-backed Union Solidarity and Development Party (USDP) to form a semi-civilian government. With Myanmar's transition from decades of military rule there have been signs of democratic reform, including greater freedom of movement, the easing of rules on protests and media censorship, a degree of greater civil and political freedoms, and the opening of limited political space through the establishment of a 
parliamentary system and the granting of elections (Jones 2014; Farrelly et al. 2018). Local communities and civil society groups have mobilized campaigns at a variety of political scales, targeting a wide range of issues related to human rights, land and natural resource governance, and legislative reform. A number of ethnic civil society organizations continue to attach these calls to the broader movement for the establishment of a democratic federal union. However, comprehensive and deep-rooted democratic reforms are impeded by the continued significant role of the Tatmadaw in Myanmar's political system, enshrined within the 2008 constitution (Egreteau 2016; KPSN 2018b; Pedersen 2018).

Between September 2011 and April 2012, the USDP government renewed and signed new ceasefires with 14 EAOs - nine of which are based in the Salween River basin area - while also initiating a multilateral peace negotiation process. Nine formal rounds of multilateral negotiations between 2013 and 2015 involving representatives of the Tatmadaw, EAOs, political parties, government, parliament and other stakeholders resulted in a Nationwide Ceasefire Agreement (NCA) in October 2015, although not all groups signed the agreement. The NCA represents the first attempt to bring every EAO under one common ceasefire text and agreement, while also containing political provisions to guide the formation of a future democratic federal union (Box 3.1 Signatories and non-signatories to the NCA).

Box 3.1: Signatories and non-signatories to the NCA. Source The authors.

Much of the negotiations over peace, conflict, and authority are still very much in process. Significantly, NCA non-signatory EAOs command 70-80\% of the country's EAO armed forces, including the United Wa State Army (UWSA), the Shan State Progressive Party (SSPP), the Ta'ang National Liberation Army (TNLA), the Myanmar National Democratic Alliance Army (MNDAA) and the National Democratic Alliance Army of Eastern Shan State (NDAA-ESS), all based or controlling territory in the Salween River basin in Shan State. In the Salween Basin, two of the largest EAOs - the Karen National Union (KNU) and the Restoration Council of Shan State (RCSS) signed the NCA in October 2015 alongside six smaller EAOs. However, the KNU and RCSS ceasefires have been put under severe strain due to persistent Tatmadaw operations in their territories and restrictions on political space for genuine political dialogue. Thus, aside from the on-paper agreements, distinctions between ceasefire and non-ceasefire groups has become increasingly opaque in the Salween basin.

As of the time of writing, three Union-level peace conferences have been held under the name of the 21st Century Panglong, most recently in July 2018. However, limited progress has been made towards sustainable nationwide peace. The ongoing "21st Century Panglong" peace process appears increasingly uncertain (TNI 2017) and the present level of armed conflict has escalated to its most intense since the 
1980s (Lintner 2016; Jolliffe 2018). Armed conflict is concentrated in the Salween basin in northern Shan state, and beyond the basin in Rakhine and Kachin states. In Karen state alone, since 2016, more than 8,500 civilians have been forced to flee Tatmadaw military operations (KPSN 2018a). ${ }^{6}$

Restrictions imposed through existing legislation, including the 2008 constitution, continues to present a road-block in peace negotiations, particularly regarding questions of territorial administration and land and natural resource governance (Bauer et al. 2018). The Burma Environmental Working Group, a coalition of ethnic CSOs, has argued that, for sustainable peace to be realized, a moratorium on new and incomplete large-scale natural resource investments must be enforced until devolved federal structures and policies can be operationalized under new federal institutions, guided by a federal constitution (BEWG 2017). Yet, legislation and policies established under the USDP-led and now NLD-led Union governments have further centralized state ownership and control over land and natural resources. For example, in 2018, revisions to the Vacant, Fallow and Virgin Land Management Law received wide criticism from civil society groups that it weakened customary land tenure rights, as well as small-holder farmers land tenure rights in general, and could undermine commitments made by the Union government within the peace negotiations (Gelbort 2018). National water policy has also increasingly defined a role for the Union-level government (Götz, Chap. 6, this volume; Sect. 3.7: Transboundary water governance below).

A fundamental issue regarding dams in the Salween basin is their relationship to contested territories in Myanmar, where there is a complex history of conflict and multiple associated claims for political authority and legitimacy (Stokke et al. 2018). There are no less than ten non-state EAOs, 18 Border Guard Forces (BGFs) and 28 militias active in the Salween Basin area (Buchanan 2016; Burke et al. 2017). South (2018: 52) differentiates between "relatively small and mostly quite remote areas controlled exclusively by EAOs and more extensive areas of mixed administration, where authority is exercised variously by one or more EAOs and the government or various Myanmar Army-backed militias." Thus, there are significant areas of the Salween basin where the central government has limited ability to project its authority (Callahan 2007; Jolliffe 2015). This includes all of the proposed and under construction projects on the Salween River basin, with the mainstream dams having the largest territorial impact often being the most contested.

Numerous analysts have linked the current plans for Salween dams to the risk of armed conflict and in some cases ongoing cases of fighting (BEWG 2017; Burke et al. 2017; Karen News 2014; Suhardiman et al. 2017). For instance, around the Hatgyi dam site, fighting between a splinter faction of the Democratic Karen Buddhist Army (DKBA) and a Tatmadaw-allied BGF has sporadically broken out, including in 2014 (KRW 2014) and 2016 (Hein 2016), and has been linked by CSO networks to plans for the project (KRW 2016; KPSN 2018a). Similarly, a

\footnotetext{
${ }^{6}$ Well over 900,000 civilians have been forcibly displaced since 2011 , including close to 800,000 Rohingya who have fled from Rakhine state.
} 
representative of the Shan Nationalities League for Democracy has suggested the Mong Ton dam could threaten the peace process and national reconciliation, a feeling echoed by CSOs (SWAN 2015; Hein 2016).

Contested political authority over territory in the Salween basin requires a different way of looking at water governance, as the assumption of a single sovereign political authority does not hold. From a hydropolitical perspective, it means that multiple claims for legitimacy to govern must be given serious regard. Yet, there are also a large number of predominantly pro-government armed actors, or militias, operating in the Salween River basin area, with a far small number allied with EAOs. Pro-government militias tend to be largest and most active in areas where the Tatmadaw has engaged in combat with the EAOs, and although they may receive direct and indirect support from the Tatmadaw many also raise additional revenues via business activities across a range of sectors, from natural resource projects such as agro-industry, logging and mining, to illicit activities such as narcotics (Buchanan 2016).

The ongoing political uncertainty around the peace negotiations, which have been stated as working towards defining a federal union in Myanmar, adds additional complexity to understanding how water is to be governed, as the foundational political agreement between the national and subnational levels of administration is not yet established. These contestations are also operating at, and generative of, various scales of mobilization and governance in terms of the peace process and with regard to water governance (Götz, Chap. 6, this volume).

\subsection{Civil Society Work Across Scales}

While above we detailed the broader political economic context and the various actors and scales invoked in the electricity trade, the evolving politics of hydropower development are also explicitly linked to the work of civils society actors (Lamb et al., Chap. 7, this volume). Momentum for the projects has been stalled as riverside communities in Thailand and Myanmar, sometimes in collaboration with a range of local, national and international CSOs, have contested and challenged the plans for large plans (Magee/Kelley 2009; Simpson 2013). Strategies have ranged from undertaking different types of research to celebrating the river and organizing protests and lodging complaints with the Myanmar Government and the National Human Rights Commission of Thailand. For example, in February 2007, a Global Day of Action Against the Salween Dams in Myanmar took place in 19 cities globally, when a petition letter endorsed by 232 organizations was also released (International Rivers 2007). These actions have continued to present (Deetes, Chap. 16, this volume).

It is important to recognize that CSOs and community-based organizations (CBOs) have sought different visions from those of large dam proponents that have 
emphasized more local, community-centered forms of development. For example, eighty kilometers downstream of the proposed Hatgyi dam the community-based NGO KESAN has been working in collaboration with five village communities around the Salween's Daw Lar Lake. The initiative, known as Community Based Water Governance, focuses on advancing local people's rights to land, natural resources and environmental conservation, and to expand civic space for community engagement in resource governance (KESAN 2018; Bright, Chap. 5, this volume). A Daw Lar Lake committee has been formed among the five villages around the lake that is now documenting the lake watershed's natural resources and seasonal livelihoods, mapping village boundaries and conservation zones, and detailing customary governance arrangements. This bottom-up initiative aspires to empower community rights "... to self-determination, which includes the right to manage and govern their own lands, water, forests and natural resources through community based institutions" (KESAN 2018: 16), given that only in 2013 the state government had tried to auction Daw Lar Lake as a commercial fishing concession to a private company without informing the communities.

Upstream of the proposed Hatgyi dam, in Karen State's Mutraw district, another grassroots-led initiative, promoting peace and self-determination, environmental integrity, and cultural survival has been steadily building momentum. This initiative is known as the Salween Peace Park. Founded on a longstanding partnership between local communities, Karen civil society and the Karen National Union (KNU), this indigenous conservation initiative has sought to

... expand the concept of "Water Governance" beyond just the water in the river itself, to include the land, forest, biodiversity, upland shifting cultivation, customary land systems, and cultural and sacred sites along the Salween River Basin. (KESAN 2017: 1)

This work has been generative of much debate and attention. Significantly, it has introduced new scales for analysis and action: a Peace Park operating with the collaboration of Karen civil society, communities and the KNU.

\subsection{Transboundary Water Governance}

Finally, we turn to the transboundary scale of the Salween River and its relationship with national and subnational scale water governance. Unlike the Mekong River, there has not yet been a significant commitment by governments to a comprehensive transboundary water cooperation agreement for the Salween River. As discussed above, existing intergovernmental agreements have focused on transboundary electricity trade rather than transboundary water cooperation. Following the aforementioned scholars' insights into 'cooperation' and what it produces (Bakker 1999; Sneddon/Fox 2006), as well as who it includes and excludes, and what it 'forgets,' we consider the extent to which transboundary arrangements have emerged to date beyond a 'comprehensive transboundary water cooperation agreement', the lack of which is itself significant. 
In Thailand, concerns over the transboundary impacts of the Salween dams in Myanmar on communities in Thailand highlight the range of actors involved, across both countries. Concerns about the cross-border impacts were, for instance, formalized and in part formed the basis for a National Human Rights Commission of Thailand (NHRCT) investigation towards the Salween dams, and in particular the Hatgyi Dam (Lamb 2014). Meanwhile, similar concerns have been raised regarding plans for cross-border water transfers from the Salween River to the Chaophraya River. Despite a series of detailed studies, including one most recently initiated in 2015 (Wipatayotin 2015), it is not certain there is consensus from Myanmar that water transfer would be acceptable (Affeltranger 2008). The impacts of the project still need to be fully assessed and made public. Meanwhile, for trans-basin water transfer projects proposed to be located within Thailand, for example those on the Yuam River or Moei River, it is not clear how Thailand would proceed with informing or negotiating with Myanmar (Interview with retired Myanmar government official 2016).

These cross-border ventures are likely to be re-assessed now, as water governance in Thailand is undergoing significant reform. A new water law was passed on 4 October 2018 that aims to consolidate 38 water-related departments across ten ministries under the Office of National Water Resources (ONWR) housed in the Prime Minister's Office. This holds uncertain implications for transboundary water governance in practice, and who would be involved or consulted in 'cooperation' efforts, and in what ways. For example, many of the international functions of the Department of Water Resources within the Ministry of Natural Resources and Environment, including the Thai National Mekong Committee, have been transferred to the ONWR.

Regarding national water governance in Myanmar, a National Water Resources Committee (NWRC) was established by presidential degree in 2013 and reconstituted in March 2016 after the elections (Aye 2016). The NWRC is comprised of 20 members from water-related state agencies, chaired by the Vice President and also has an Advisory Group made up of water experts (Aye 2016). In 2014, the NWRC published Myanmar's National Water Policy and subsequently a National Water Framework Directive that broadly adopts the principles of Integrated Water Resources Management (NWRC 2014; Nesheim et al. 2016). While national in scope, in practice a principle focus of the NWRC has been the Irrawaddy River. On the Salween River, the limited capacity of the central government to project authority across the basin has constrained the implementation of the National Water Policy. There has, however, recently been some discussion on the preparation of a Salween policy and potentially a Salween River Basin Organization. Yet, it would be important to heed concerns around bilateral or MRC-like cooperation that have been critiqued for their apolitical nature and ability to obscure or depoliticize the concerns of affected peoples (see for instance Salween University Network Meeting 2016; Sneddon/Fox 2006). 


\subsection{Salween Cooperation Through the Lens of Hydropolitics}

In this section, we ask what does 'cooperation' mean, who is included or excluded, what is foregrounded versus forgotten, and what are the implications for the future of the basin. We suggest that a hydropolitics lens helps reveal and analyze the means through which water becomes politicized.

One mode of cooperation has emerged around the pursuit of large hydropower projects in the basin. Here the chapter has sought to draw attention to the long history of these projects, and the role played by various iterations of bilateral and regional inter-government political and economic cooperation, as well as the role of domestic and international project developers. This mode of cooperation which assumes common pursuit of large hydropower has been backed up by commissioned technical studies that focus on project feasibility in terms of engineering and economic considerations. Cooperation for the projects in Myanmar is largely framed around cross-border power trade relations, either with Thailand or China. At the same time, this mode of cooperation foregrounds national and regional development which often privilege particular terms of economic growth. Largely forgotten from these formal processes are affected communities and non-state actors such as electricity consumers, and in this particular case, Myanmar's EAOs and CSOs.

However, through various strategies, these actors have shaped and challenged the projects and their terms, for example through the NHRCT in the case of the Hatgyi dam. This case flagged, among other issues, the social impacts of the project, including from a human rights perspective, and their security implications. Meanwhile violent conflict in project areas appears linked at least partly to ensuring territorial control of project sites, and has created severe impacts on communities who live within the contested areas. Natural resource governance and 'resource sharing' is a theme within the ongoing peace negotiations, but to date has not been thoroughly discussed as political space to address even more fundamental political questions remains foreclosed by the Tatmadaw's influence over the process that is enshrined within the 2008 constitution.

A very different mode of cooperation has focused on community-based initiatives, such as the Salween Peace Park. Here, viewed through a hydropolitics lens, a different set of actors have sought to produce a vision for the future of the Salween River. Significantly, it is also an initiative emerging from a sense of history, but one that is narrated from territorial claims linked to the Karen people's calls for self-determination - a call shared by myriad ethnic groups in the Salween River basin and across the country. Inevitably, the violent conflict also shapes this sense of history and has in part forged the notion that there should be a peace park. Cooperation is between CSOs, the KNU and communities, while recognition of legitimacy is sought from a wider array of actors that range from the international 
community to the Union government. In this mode of cooperation, foregrounded are the Karen communities' claims for political authority, alongside CSOs and the KNU, who are organized through community-based institutions. In contrast to the first mode of cooperation, it is the Union government's political authority to govern resources such as water and land that is questioned. Local ecological knowledge is also emphasized, as well as a range of other studies produced by groups such as KESAN that addresses issues such as biodiversity and suitable forms of governance.

\subsection{Conclusion}

This chapter has sought to analyze the Salween basin through the lens of hydropolitics, with a focus on Myanmar. It has drawn attention to the multi-scaled processes and multiple actors involved, including for water governance and electricity governance, which intersect in the planning and materialization of large hydropower dams. These projects are advanced by consortiums formed of transnational corporations from Thailand and China working with Myanmar companies, and backed by various Myanmar and Thai government agencies via bilateral and regional agreements and through national planning processes.

We have also sought to draw out how scale itself is produced through these contested processes. Proponents of large dams have framed them as a "development solution" for the Salween basin via promoting regional connectivity, industrialization, electrification and associated poverty alleviation. Yet, this frame has also been contested at different scales, in particular by EAOs, CSOs and INGOs across a range of issues including on human rights, environment and social impacts, and the ongoing prevalence of conflict in the context of the ongoing peace negotiations and assertions by some actors for democratic federalism. Meanwhile, civil society collaborations for the Salween Peace Park also reconceptualize and decentralize water governance. These efforts not only position the actors involved as agents in water governance, but also rethink the scales of governance across local and subnational arenas.

Finally, it is the history of conflict in the Salween Basin, which remains unresolved to this day, that must be foregrounded as a key issue in how plans for large dams on the Salween River have unfolded. In the technical documents of planners, the issue of conflict is not really acknowledged, or is only recently so (i.e., ICEM 2017), but on the ground conflict and security fundamentally determine project outcomes including for potentially impacted communities. Given the technical, legal, and political complexity of these large dams and the great uncertainty in Myanmar's ongoing peace process, there is a strong argument that Myanmar's peace negotiations need to be concluded before such projects are discussed as a part of a broader discussion on resource governance in the context of federalism. 


\section{References}

ADB (Asian Development Bank). (2012a). The Greater Mekong Subregion at 20: Progress and prospects. Mandaluyong City, Philippines: Asian Development Bank. Retrieved from: https:// www.adb.org/sites/default/files/publication/30064/gms-20-yrs-progress-prospects.pdf.

ADB (Asian Development Bank). (2012b). The Greater Mekong Subregion power trade and interconnection: 2 decades of cooperation. Mandaluyong City, Philippines: Asian Development Bank.

ADB (Asian Development Bank). (2015). Myanmar 2015 Energy Master Plan (EMP). Mandaluyong City, Philippines: Asian Development Bank.

Affeltranger, B. (2008). Inter-basin water transfers as a technico-political option: Thai-Burmese projects on the Salween River. In N.I Pachova, M. Nakayama \& L. Jansky (Eds.), International water security: Domestic threats and opportunities (pp. 161-179). Tokyo, Japan: United Nations University Press.

Aye, S.P. (2016, July 11). Re-launched committee to manage water resources. Myanmar Times. Retrieved from: https://www.mmtimes.com/national-news/21308-re-launched-committee-tomanage-water-resources.html.

Bakker, K. (1999). The politics of hydropower: developing the Mekong. Political Geography, 18 (2): 209-232.

Bauer, A., Kirk, N., \& Sahla, S. (2018). Natural resource federalism: Considerations for Myanmar. Natural Resource Governance Institute. Retrieved from: https://resourcegovernance. $\mathrm{org} / \mathrm{sites} /$ default/files/documents/federalism-considerations-form-myanmar.pdf.

BEWG (Burma Environment Working Group). (2017). Resource federalism: A roadmap for decentralized governance of Burma's natural heritage.

Buchanan, J. (2016). Militias in Myanmar. San Francisco, CA: The Asia Foundation.

Burke, A., Williams, N., Barron, P., Jolliffe, K., \& Carr, T. (2017). The contested areas of Myanmar: Subnational conflict, aid and development. San Francisco, CA: The Asia Foundation.

Callahan, M. (2007). Political authority in Burma's ethnic minority states: Devolution, occupation and coexistence. Washington, DC: East-West Center.

Deetes, P. (2016, September 29). Salween dams threaten river communities. Bangkok Post. Retrieved from: https://www.bangkokpost.com/opinion/opinion/1097621/salween-damsthreaten-river-communities.

Delina, L.L. (2018). Whose and what futures? Navigating the contested coproduction of Thailand's energy sociotechnical imaginaries. Energy Research \& Social Science, 35, 48-56.

EGATi (EGAT International). (2016). EGATi Upper Thanlwin Hydropower Project (Mong Ton). Retrieved from: http://www.egati.co.th/en/investment/en-mongton.html.

Egreteau, R. (2016). Caretaking democratization: The military and political change in Myanmar. Oxford University Press.

EPPO (Energy Policy and Planning Office). (2015). Thailand Power Development Plan 20152036 (PDP2015). Bangkok, Thailand: EPPO, Ministry of Energy.

Farrelly, N., Holliday, I., \& Simpson, A. (2018). Explaining Myanmar in flux and transition. In A. Simpson, N. Farrelly \& I. Holliday (Eds.), Routledge handbook of contemporary Myanmar (pp. 3-12). London and New York: Routledge.

Gelbort, J. (2018, December 10). Implementation of Burma's Vacant, Fallow and Virgin Land Management Law: At Odds with the Nationwide Ceasefire Agreement and Peace Negotiations. Transnational Institute. Retrieved from: https://www.tni.org/en/article/implementation-ofburmas-vacant-fallow-and-virgin-land-management-law.

Greacen, C.S., \& Greacen, C. (2004). Thailand's electricity reforms: Privatization of benefits and socialization of costs and risks. Pacific Affairs, 77(3), 717-541.

Hein, K.S. (2016, October 20). Activists damn Salween plans. Frontier Myanmar. Retrieved from: https://frontiermyanmar.net/en/activists-damn-salween-plans. 
ICEM (International Center for Environmental Management). (2017). Baseline assessment report hydropower: Strategic environmental assessment of the hydropower sector in Myanmar. Washington, DC: International Finance Corporation.

International Finance Corporation (IFC) (2018). Strategic Environmental Assessment (SEA) of the Myanmar hydropower sector. IFC. Washington, DC.

International Rivers. (2007, February 18). Worldwide protests against Salween Dams in Burma. Retrieved from: https://www.internationalrivers.org/resources/worldwide-protests-againstsalween-dams-in-burma-3900.

IRN (International Rivers Network). (1999). Power struggle: The impacts of hydro-development in Laos. Berkeley, CA: International Rivers Network.

Jolliffe, K. (2015). Ethnic armed conflict and territorial administration in Myanmar. Yangon, Myanmar: The Asia Foundation.

Jolliffe, K. (2018). Peace and reconciliation. In A. Simpson, N. Farrelly \& I. Holliday (Eds.), Routledge handbook of contemporary Myanmar (pp. 359-370). London and New York: Routledge.

Jones, L. (2014). The political economy of Myanmar's transition. Journal of Contemporary Asia, 44(1), 144-170.

Karen News. (2014, October 5). Fighting 'directly linked' to Hat Gyi Dam Project - Claim Karen leadership. Karen News. Retrieved from: http://karennews.org/2016/10/fighting-directlylinked-to-hat-gyi-dam-project-claim-karen-leadership/.

KRW (Karen Rivers Watch). (2014). Afraid to go home: Recent violent conflict and human rights abuses in Karen State.

KRW (Karen Rivers Watch). (2016). Karen State September 2016 Conflict: The real motivations behind renewed war.

KDRG (Karenni Development Research Group). (2006). Damned by Burma's generals: The Karenni experience with hydropower development - From Lawpita to Salween.

KWU (Kayan Women's Union). (2008). Drowning the green ghosts of Kayan Land: Impacts of the upper Paunglaung Dam in Burma.

Kean, T. (2018, August 9). Hydropower is back. Frontier Myanmar. Retrieved from: https:// frontiermyanmar.net/en/hydropower-is-back.

KESAN (Karen Environmental and Social Action Network). (2017). The Salween Peace Park: A Scoping Study (unpublished). Yangon, Myanmar: KESAN.

KESAN (Karen Environmental and Social Action Network). (2018). Community based water governance: A briefing report on Daw Lar Lake. Yangon, Myanmar: KESAN. Forthcoming.

KPSN (Karen Peace Support Network). (2018a). The nightmare returns: Karen hopes for peace and stability dashed by Burma Army's actions.

KPSN (Karen Peace Support Network). (2018b). Burma's dead-end peace negotiation process: A case study of the land sector.

Lamb, V. (2014). Making governance good: The production of scale in the environmental impact assessment and governance of the Salween River. Conservation and Society, 12(4), 386-397.

Lebel, L., Garden, P., \& Imamura, M. (2005). The politics of scale, position, and place in the governance of water resources in the Mekong region. Ecology and Society, 10(2), 18.

Lin, J., Liu, X., \& Kahrl, F. (2016). Excess capacity in China's power systems: A regional analysis. Commissioned by the Energy Foundation through the U.S. Department of Energy. Berkeley, CA: Ernest Orlando Lawrence Berkeley National Laboratory.

Lintner, B. (2016, October 11). Burma's misguided peace process needs a fresh start. The Irrawaddy. Retrieved from: http://www.irrawaddy.com/opinion/commentary/burmasmisguided-peace-process-needs-a-fresh-start.html.

Magee, D. (2006). Powershed politics: Yunnan hydropower under great western development. China Quarterly, 185, 23-41.

Magee, D., \& Kelley, S. (2009). Damming the Salween River. In F. Molle, T. Foran \& M. Käkönen (Eds.), Contested waterscapes in the Mekong Region: Hydropower, livelihoods and governance (pp. 115-140). London, United Kingdom: Earthscan and USER (Chiang Mai University, Thailand). 
Middleton, C. (2018). Policy brief: Reciprocal transboundary cooperation on the Lancang-Mekong River: Towards an inclusive and ecological relationship. Bangkok, Thailand: Center for Social Development Studies, Faculty of Political Science, Chulalongkorn University.

Middleton, C., \& Allouche, J. (2016). Watershed or powershed? Critical hydropolitics, China and the 'Lancang-Mekong Cooperation Framework'. The International Spectator, 51(3), 100-117.

Middleton, C., \& Dore, J. (2015). Transboundary water and electricity governance in mainland Southeast Asia: Linkages, disjunctures and implications. International Journal of Water Governance, 3(1), 93-120.

MOEP (Ministry of Electric Power). (February 2011). Environmental Impact Assessment (EIA) and Social Impact Assessment (SIA). Baluchaung No.3 Hydropower Project. Retrieved from: https://www.shwetaunggroup.com/wp-content/uploads/2017/03/Baluchaung-No3Hydropower-Project-ESIA-Report.pdf.

Molle, F. (2007). Scales and power in river basin management: The Chao Phraya River in Thailand. The Geographical Journal, 173(4): 358-373.

Myanmar Eleven. (2016, August 14). Myanmar pushes for more hydropower projects. The Nation. Retrieved from: http://www.nationmultimedia.com/business/Myanmar-pushes-for-morehydropower-projects-30292893.html.

Nesheim, I., Wathne, B.M., Ni, B., \& Tun, Z.L. (2016). Myanmar: Pilot introducing the national water framework directive. Water Solutions, 1, 18-27.

Norconsult. (1994). Promoting subregional cooperation among Cambodia, Lao PDR, Myanmar, Thailand, Viet Nam and Yunnan Province of the People's Republic of China: Subregional energy sector study for the Asian Development Bank. Mandaluyong City, Philippines: Asian Development Bank.

NWRC (National Water Resources Committee). (2014). Myanmar National Water Policy. Yangon, Myanmar: Ministry of Transport.

Paoletto, G., \& Uitto, J.I. (1996). The Salween River: is international development possible? Asia Pacific Viewpoint, 37(3): 269-282.

Pedersen, M.B. (2018). Democracy and human rights. In A. Simpson, N. Farrelly \& I. Holliday (Eds.), Routledge handbook of contemporary Myanmar (pp. 371-280). London and New York: Routledge.

Pollard, J. (2018, February 11). Myanmar power plans could spare the Salween. Asia Times Online. Retrieved from: https://burmariversnetwork.org/news/myanmar-power-plans-couldspare-the-salween.html.

Ptak, T. (2014). Dams and development: Understanding hydropower in Far Western Yunnan Province, China. Focus on Geography, 57(2), 43-53.

Ptak, T., \& Hommel, D. (2016). The trans-political nature of Southwest China's energy conduit, Yunnan Province. Geopolitics, 21(3), 556-578.

Rogers, S., \& Crow-Miller, B. (2017). The politics of water: a review of hydropolitical frameworks and their application in China. Wiley Interdisciplinary Reviews: Water 4(6): e1239.

Salween University Network Meeting. (2016, January 29-31). Shared Vision. Retrieved from: https://www.academia.edu/29283801/Meeting_Report_TOWARDS_A_SHARED_VISION_ FOR_THE_SALWEEN-THANLWIN-NU_.

Salween Watch Coalition. (2016). Current status of dam projects on the Salween River.

Simpson, A. (2013). Challenging hydropower development in Myanmar (Burma): cross-border activism under a regime in transition. The Pacific Review, 26(2), 129-152.

Sneddon, C. (2002). Water conflicts and river basins: the contradictions of co-management and scale in northeast Thailand. Society and Natural Resources, 15(8), 725-741.

Sneddon, C., \& Fox, C. (2006). Rethinking transboundary waters: A critical hydropolitics of the Mekong basin. Political Geography, 25(2), 181-202.

South, A. (2018). Hybrid governance and the politics of legitimacy in the Myanmar peace process. Journal of Contemporary Asia, 48(1), 50-66.

Stokke, K., Vakulchuk, R., \& Øverland, I. (2018). Myanmar: A political economy analysis. Oslo: Norwegian Institute of International Affairs. 
Straits Times. (2017, August 5). China in talks to sell electricity to Myanmar. Straits Times. Retrieved from https://www.straitstimes.com/asia/se-asia/china-in-talks-to-sell-electricity-tomyanmar.

Suhardiman, D., Rutherford, J., \& Bright, S.J. (2017). Putting violent armed conflict in the center of the Salween hydropower debates. Critical Asian Studies, 49(3): 349-364.

SWAN (Shan Women's Action Network). (2015). Naypyidaw must cancel its latest plans to build the Upper Salween (Mong Ton) dam in Shan State [Press release].

TERRA (Towards Ecological Recovery and Regional Alliance). (2006). Chronology of Salween dam plans (Thailand and Burma). Bangkok, Thailand: TERRA.

TNI (Transnational Institute). (2017). Beyond Panglong: Myanmar's national peace and reform dilemma. Amsterdam, The Netherlands: TNI.

Vatcharasinthu, C., \& Babel, M.S. (1999). Hydropower potential and water diversion from The Salween Basin. Workshop on trans-boundary waters: The Salween Basin. Chiang Mai, Thailand.

Wipatayotin, A. (2015, July 18). RID pushes two new water diversion bids. Bangkok Post, Retrieved from: https://www.bangkokpost.com/print/626428/.

Yee, T. H. (2018, May 7). Work on Myanmar dam goes on under heavy guard. The Straits Times. Retrieved from: https://www.straitstimes.com/asia/se-asia/work-on-myanmar-dam-goes-onunder-heavy-guard.

Yu, X., Chen, X., Middleton C., \& Lo, N. (March 2018). Charting new pathways towards inclusive and sustainable development of the Nu River Valley. Kunming and Bangkok: Green Watershed and Center for Social Development Studies, Faculty of Political Science, Chulalongkorn University.

Open Access This chapter is licensed under the terms of the Creative Commons Attribution 4.0 International License (http://creativecommons.org/licenses/by/4.0/), which permits use, sharing, adaptation, distribution and reproduction in any medium or format, as long as you give appropriate credit to the original author(s) and the source, provide a link to the Creative Commons license and indicate if changes were made.

The images or other third party material in this chapter are included in the chapter's Creative Commons license, unless indicated otherwise in a credit line to the material. If material is not included in the chapter's Creative Commons license and your intended use is not permitted by statutory regulation or exceeds the permitted use, you will need to obtain permission directly from the copyright holder. 